\title{
Neutrophils Kill Reactive Oxygen Species- Resistant Pseudomonas aeruginosa by Sphingosine
}

\author{
Katrin Anne Becker ${ }^{\mathrm{a}} \quad$ Xiang Li $^{\mathrm{b}}$ Aaron Seitz ${ }^{\mathrm{c}}$ Joerg Steinmann ${ }^{\mathrm{d}}$ Anne Koch \\ Edward Schuchman ${ }^{\mathrm{N}}$ Markus Kamler ${ }^{f}$ Michael J. Edwards ${ }^{c}$ Charles C. Caldwellc \\ Erich Gulbins ${ }^{\mathrm{a}, \mathrm{c}}$ \\ aDepartment of Molecular Biology, University Hospital Essen, University of Duisburg-Essen, Essen, \\ Germany; ${ }^{b}$ Department of Pharmacological \& Pharmaceutical Sciences, College of Pharmacy, University \\ of Houston, Houston, TX, USA; 'Department of Surgery, University of Cincinnati College of Medicine, \\ Cincinnati, Ohio, USA; 'Institute of Medical Microbiology, University of Hospital Essen, University \\ of Duisburg-Essen, Essen, Germany; ' Department of Genetics \& Genomic Sciences, Ichan School of \\ Medicine at Mount Sinai, New York, NY, USA; 'Department of Thoracic and Cardiovascular Surgery, \\ West German Heart and Vascular Center Essen, University Hospital Essen, Essen, Germany
}

\section{Key Words}

Reactive oxygen species $\cdot$ Sphingosine $\cdot$ Neutrophils $\cdot$ Pseudomonas aeruginosa $\cdot$ Pneumonia

\begin{abstract}
Background/Aims: Cystic fibrosis (CF) is dominated by chronic inflammation and infection of the lung resulting in lung destruction and early death of patients. The lungs of CF patients are characterized by a massive accumulation of neutrophils. It requires definition why these massive numbers of neutrophils fail to eliminate typical CF pathogens like Staphylococcus aureus and Pseudomonas aeruginosa ( $P$. aeruginosa) in CF lungs. Methods: We determined ceramide, sphingosine and reactive oxygen species (ROS) in neutrophils from wildtype and CF mice and determined the effect of sphingosine and ROS alone or in combination on killing of different $P$. aeruginosa strains. Results: We demonstrate that wildtype neutrophils are able to kill non-mucoid and mucoid clinical $P$. aeruginosa strains, while neutrophils from CF mice are insufficient to kill these $P$. aeruginosa strains, although both types of neutrophils infected with $P$. aeruginosa produce comparable levels of superoxide. All three analyzed $P$. aeruginosa strains are resistant to reactive oxygen species. The inability of CF neutrophils to kill $P$. aeruginosa is caused by a marked decrease of surface sphingosine levels in CF neutrophils. Wildtype neutrophils contain much higher concentrations of surface sphingosine than CF neutrophils. Further, wildtype neutrophils, but not CF neutrophils, release sphingosine, most likely as microparticles, upon infection. Sphingosine kills $P$. aeruginosa in vitro at low micromolar concentrations. Reconstitution of sphingosine in CF neutrophils restores their ability to kill these pathogens, demonstrating the significance of sphingosine for bacterial killing. Conclusion: The data provide evidence for a new paradigm explaining how neutrophils kill ROS-resistant $P$. aeruginosa, i.e. by sphingosine that kills $P$. aeruginosa at low concentrations. This mechanism is defective in CF neutrophils.




\section{Cellular Physiology Cell Physiol Biochem 2017;43:1603-1616

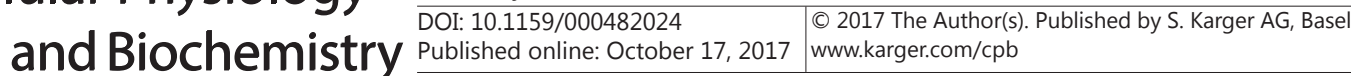 \\ Becker et al.: Regulation of Neutrophil Function in Cystic Fibrosis}

\section{Introduction}

Cystic fibrosis (CF) is caused by mutations of the cystic fibrosis transmembrane conductance regulator (CFTR) [1]. With 1 of 2,500 births, the disease is the most common autosomal recessive disorder in the EU and the USA, with approximately 80,000 persons affected [2]. At present, the most important CF-related clinical problems are pulmonary; these problems determine life expectancy, whereas the gastrointestinal problems associated with CF are relatively well controlled [2]. Pulmonary problems include chronic inflammation, fibrosis, and recurrent and chronic bacterial infections with Staphylococcus aureus (S. aureus), Pseudomonas aeruginosa (P. aeruginosa), Burkholderia cepacia, Haemophilis influenzae, and others [3]. The molecular mechanisms that lead to CF patients' high infection susceptibility are not completely known.

Because CFTR exhibits chloride channel activity, it was speculated, on the basis of in vitro studies, that water absorption from the mucus present on the epithelial cells of the respiratory tract may be altered in $\mathrm{CF}$, and that these alterations may reduce mucociliary clearance and the ability to eliminate P. aeruginosa $[4,5]$. The increased viscosity of the mucus may also affect the ability of neutrophils to migrate to and kill bacteria in the respiratory tract [5]. However, in vivo studies involving CF mice and CF patients failed to demonstrate a significant and uniform reduction in mucociliary clearance [6]. Furthermore, CF patients do not seem to exhibit a general defect of neutrophil function as a potential explanation for the high susceptibility to infection, although some distinct changes of neutrophil were reported $[7,8]$.

A recent study demonstrated that CF mice lack the ATP12A channel [9] compared to pigs and patients with CF. The ATP1AL1 gene encodes the ATP12A protein, which is the catalytic subunit of the ouabain-sensitive $\mathrm{H}^{+} / \mathrm{K}^{+}$-ATPase [10]. The protein catalyzes the hydrolysis of ATP and thereby allows the transport of $\mathrm{H}^{+}$and $\mathrm{K}^{+}$over membranes. It is expressed in various tissues and also named $\mathrm{H}^{+} / \mathrm{K}^{+}$transporting, nongastric, alpha polypeptide. Expression of ATP12A in CF pigs and patients resulted in airway acidification and therefore a higher susceptibility to chronic bacterial infections of these species compared to CF mice. Thus, while the lungs of CF mice contained approximately 100 colony forming units (CFU) 3 days after exposure to bacteria, they contained 10,000 CFU if ATP12A was expressed in the lung by adenoviral infection [9].

While these findings explain at least in part the reduced susceptibility of CF mice to chronic bacterial infections, they do not explain the very early phase of a pulmonary infection and the defense mechanisms in the lung that allow the bacteria to initiate the infection, or vice versa how the host organism prevents bacterial colonization.

We and others have previously shown that ceramide concentrations are increased in bronchial and tracheal epithelial cells and in CF alveolar macrophages [11-21]. A recent study indicated that specific ceramide species, i.e. C16 ceramide, which seem to be proinflammatory, are increased in CF lungs, while other ceramide species that might be antiinflammatory, in particular C24 ceramide, are decreased [22]. The various studies used biochemical techniques, fluorescence microscopy, mass spectrometry and in situ surface kinase assays of mouse and human tissues to show that ceramide accumulates in the trachea, bronchi, and nasal epithelial cells of CF patients and various Cftr-deficient mouse strains [11-21]. Partial inhibition of acid sphingomyelinase (Asm) activity [23, 24], achieved genetically or pharmacologically, normalized tracheal and bronchial ceramide levels and prevented bacterial infections of CF mice $[11,12,19,21]$. These studies demonstrated that increased concentrations of ceramide in bronchial epithelial cells of $C f t r$-deficient mice mediate the high susceptibility of $C f t r$-deficient mice to acute pulmonary infections with $P$. aeruginosa, and trigger chronic pulmonary inflammation and deposition of DNA in bronchi. Normalization of ceramide concentrations by genetic or pharmacological means also normalizes these changes. Several studies indicated that increased ceramide concentrations in the plasma membrane of CF epithelial cells alters the biophysical properties of these membranes and results in the formation of ceramide enriched membrane platforms [21, 
25-31]. These domains trap $\beta 1$-integrin molecules, which results in a downregulation of acid ceramidase and a further increase of ceramide and a decrease of sphingosine in CF bronchial epithelial cells [19-21, 30,31]. The decrease of sphingosine in an environement of increased ceramide concentrations facilitates acute infections in CF lungs [19-21].

In addition, we have recently demonstrated that sphingosine is abundantly expressed on the luminal surface of human nasal epithelial cells obtained from healthy persons and on the trachea and large bronchi of wildtype mice, whereas it is almost undetectable on the surface of nasal epithelial cells from CF patients and in tracheal and bronchial cells from CF mice [19-21]. Inhalation of ceramidase, which degrades ceramide and produces sphingosine, or of sphingosine not only restored sphingosine levels on the surface of CF tracheal epithelial cells, but also prevented or eliminated existing pulmonary infections of CF mice with several P. aeruginosa or $S$. aureus strains [19-21].

The role of sphingolipids for the response of neutrophils to $P$. aeruginosa is unknown. It is also unknown whether these lipids are altered in CF neutrophils and whether a change in these lipids contributes to the failure of CF neutrophils to kill pathogens in the lung. We therefore investigated whether both reactive oxygen species, that are typically released by activated neutrophils, and sphingolipids are required to mediate bactericidal effects of CF neutrophils. Here, we demonstrate that the release of superoxide from neutrophils is not altered by Cftr-deficiency, while the levels of sphingosine are greatly reduced in these cells. Neutrophils release sphingosine, most likely in sphingosine containing microparticles, upon infection with $P$. aeruginosa. Sphingosine kills several clinical $P$. aeruginosa strains at low micromolar concentrations, while reactive oxygen species are largely ineffective at least in the clinical strains used in the present study. The reduction of sphingosine causes the reduced bacterial killing by CF neutrophils, even if normal amounts of reactive oxygen species are formed. Reconstitution of sphingosine in CF neutrophils restores bacterial killing.

\section{Materials and Methods}

\section{Human samples}

Biopsies from explanted CF or donor lungs were fixed in 4\% PFA, serially dehydrated with an ethanol to xylol gradient and embedded in paraffin. The specimen were sectioned at $7 \mu \mathrm{m}$, dewaxed and rehydrated. The specimens were then stained with hemalaun for $60 \mathrm{sec}$. The samples were finally embedded in Mowiol and analyzed by a Leica fluorescence microscope SP5. The studies were approved by the local ethics committees, all patients gave informed consent.

\section{Mice}

We used $C f t r^{\text {tm1Unc-Tg }}{ }^{(\text {FABPCFTR })}$ mice $(C f t r /$; Jackson Laboratory, Bar Harbor, ME, USA) backcrossed for more than 10 generations onto the C57BL/6 background. These mice are deficient in $C f t r$ in all organs except the intestine, where they express human CFTR under the control of a fatty acid binding protein (FABP) promoter. Expression of intestinal CFTR prevents intestinal obstruction and allows feeding of the mice with a normal diet. Littermates were used as controls.

\section{Neutrophils}

Bone marrow-derived neutrophils were obtained by flushing the long bones of the legs from wildtype and CF mice using PBS. The cells were then overlayed on a Percoll/Ficoll gradient, centrifuged for $20 \mathrm{~min}$ at 800xg (no brake) and the cells in the intermediate phase were collected. Cells were washed twice, counted and resuspended in RPMI-1640 supplemented with 10 mM HEPES (pH 7.4, Carl Roth GmbH, Karlsruhe, Germany), $2 \mathrm{mM}$ L-glutamine, $1 \mathrm{mM}$ sodium pyruvate, $100 \mu \mathrm{M}$ nonessential amino acids, $100 \mathrm{U} / \mathrm{mL}$ penicillin, $100 \mu \mathrm{g} / \mathrm{mL}$ streptomycin (all from Invitrogen) and $10 \%$ fetal calf serum. Cells were allowed to rest for $60 \mathrm{~min}$, washed once in HEPES/saline (H/S, consisting of $20 \mathrm{mM}$ HEPES, $132 \mathrm{mM} \mathrm{NaCl}, 5 \mathrm{mM} \mathrm{KCl}, 1$ $\mathrm{mM} \mathrm{CaCl}_{2,} 0,7 \mathrm{mM} \mathrm{MgCl}_{2}, 0,8 \mathrm{mM} \mathrm{MgSO}_{4}, \mathrm{pH} \mathrm{7,4)}$ and then used for experiments.

\section{Bacteria}

We used three clinical P. aeruginosa isolates, named 762 [25, 32], 1242 and 1245 [21]. The strain 762 was from a patient with P. aeruginosa sepsis, 1242 and 1245 from CF patients. 1242 and 1245 are 


\section{Cellular Physiology Cell Physiol Biochem 2017;43:1603-1616 \begin{tabular}{l|l|l} 
DOI: 10.1159/000482024 & $\begin{array}{l}\text { O 2017 The Author(s). Published by S. Karger AG, Basel } \\
\text { www.karger.com/cpb }\end{array}$
\end{tabular}

multidrug-resistant mucoid P. aeruginosa strains. The strain 762 is a multidrug-resistant non-mucoid strain. Bacteria were plated from frozen stocks on fresh tryptic soy agar plates (TSA; Becton Dickinson), grown at $37^{\circ} \mathrm{C}$ for 14 to 16 hours. The P. aeruginosa strain 762 was then resuspended in $40 \mathrm{~mL}$ tryptic soy broth (Becton Dickinson), warmed to $37^{\circ} \mathrm{C}$, to an optical density of 0.225 at $550 \mathrm{~nm}$. The bacterial suspension was incubated at $37^{\circ} \mathrm{C}$ for $1 \mathrm{hr}$ with shaking at $125 \mathrm{rpm}$ to obtain bacteria in the early logarithmic growth phase. Bacteria were washed twice and resuspended in warmed $10 \mathrm{mM}$ HEPES, $63 \mathrm{mM} \mathrm{NaCl}, 2.4 \mathrm{mM} \mathrm{KCl}$, $1.2 \mathrm{mM} \mathrm{CaCl}_{2}, 1.9 \mathrm{mM} \mathrm{MgSO}_{4}, \mathrm{pH} 6.8$ ), which is similar to the ion concentration in the airway surface liquid (named ASL-buffer) [33]. The final concentration of bacteria was quantified by photospectrometry. The mucoid strains 1242 and 1245 were directly taken from the agar plate, resuspended in ASL-buffer and used at the appropriate concentration.

\section{Superoxide measurements}

Superoxide production was determined by electron spin resonance (ESR), as previously described [34]. Neutrophils were infected with 100 bacteria per cell for the indicated times and shock frozen in liquid nitrogen. Proteins were isolated and resuspended in modified Krebs-HEPES buffer containing deferoxamine $(100 \mu \mathrm{M}$, Sigma) and diethyldithiocarbamate ( $5 \mu \mathrm{M}$, Sigma). A spin trap, 1-hydroxy-3-methoxycarbonyl-2, 2,5, 5-tetramethylpyrrolidine (CMH; Noxygen Science Transfer \& Diagnostics, Elzach, Germany; $1 \mathrm{mM}$ final concentration), was then added to the mixture in the presence or absence of manganese-dependent superoxide dismutase (SOD, $200 \mathrm{U} / \mathrm{mL}$; Sigma-Aldrich). The latter served to calibrate the system. $\mathrm{O}_{2}$ production in the mixture was then kinetically analyzed over a period of 10 min using a Miniscope MS400. The ESR settings were as follows: biofield, 3, 350; field sweep, $60 \mathrm{G}$; microwave frequency, $9.78 \mathrm{GHz}$; microwave power, $20 \mathrm{~mW}$; modulation amplitude, $3 \mathrm{G}$; points of resolution, 4, 096; receiver gain, 100; and kinetic time, $10 \mathrm{~min}$.

\section{Measurement of total cellular sphingosine}

Neutrophils $\left(2 \times 10^{6}\right.$ cells $)$ were resuspended in $200 \mu \mathrm{H} / \mathrm{S}$ and infected at $37^{\circ} \mathrm{C}$ with P. aeruginosa strain 762 at a multiplicity of infection (MOI) of 1 cell per 100 bacteria or left uninfected. In a first set of experiments the total samples were extracted in $600 \mu \mathrm{lHCl}_{3} / \mathrm{CH}_{3} \mathrm{OH} / 1 \mathrm{~N} \mathrm{HCl}(100: 100: 1, \mathrm{v} / \mathrm{v} / \mathrm{v})$. Second, after the infection time, the samples were centrifuged for $7 \mathrm{~min}$ at $150 \mathrm{xg}$ at $4^{\circ} \mathrm{C}$, the supernatant was collected and the pellet was extracted in $200 \mu \mathrm{l}$ water and $600 \mu \mathrm{l} \mathrm{CHCl} / \mathrm{CH}_{3} \mathrm{OH} / 1 \mathrm{~N} \mathrm{HCl}$ (100:100:1, $\mathrm{v} / \mathrm{v} / \mathrm{v}$ ). The supernatant was extracted in $600 \mu \mathrm{l} \mathrm{CHCl}_{3} / \mathrm{CH}_{3} \mathrm{OH} / 1 \mathrm{~N} \mathrm{HCl}(100: 100: 1, \mathrm{v} / \mathrm{v} / \mathrm{v})$. This fraction was considered as microparticle and bacteria fraction. After extraction, the lower phase was dried and resuspended in a detergent solution $(7.5 \%$ [w/v] n-octyl glucopyranoside, $5 \mathrm{mM}$ cardiolipin in $1 \mathrm{mM}$ diethylenetriaminepentaacetic acid). The kinase reaction was initiated by adding 0.004 units sphingosine kinase 1 (R\&D) in $50 \mathrm{mM}$ HEPES (pH 7.4), $250 \mathrm{mM} \mathrm{NaCl}, 30 \mathrm{mM} \mathrm{MgCl}, 1 \mu \mathrm{M}$ ATP, and $5 \mu \mathrm{Ci}\left[{ }^{32} \mathrm{P}\right] \gamma \mathrm{ATP}$. Samples were incubated for $1 \mathrm{hr}$ at $37^{\circ} \mathrm{C}$ with shaking (350 rpm) and then extracted in $20 \mu \mathrm{l} 1 \mathrm{~N} \mathrm{HCl}, 800$ $\mu \mathrm{l} \mathrm{CHCl} / \mathrm{CH}_{3} \mathrm{OH} / 1 \mathrm{~N} \mathrm{HCl}(100: 200: 1, \mathrm{v} / \mathrm{v} / \mathrm{v}), 240 \mu \mathrm{CHCl}_{3}$, and $2 \mathrm{M} \mathrm{KCl}$. The lower phase was collected, dried, dissolved in $20 \mu \mathrm{L}$ of $\mathrm{CHCl}_{3}: \mathrm{CH}_{3} \mathrm{OH}(1: 1, \mathrm{v} / \mathrm{v})$, and separated by Silica G60 thin-layer chromatography (TLC) using $\mathrm{CHCl}_{3} / \mathrm{CH}_{3} \mathrm{OH} /$ acetic acid/ $\mathrm{H}_{2} \mathrm{O}(90: 90: 15: 5, \mathrm{v} / \mathrm{v} / \mathrm{v} / \mathrm{v})$. The TLC plates were analyzed with a phosphorimager.

\section{Measurement of surface sphingosine}

Neutrophils were prepared as above, rested for $1 \mathrm{hr}$ in RPMI-1640 supplemented as above and washed once in H/S. The pellets were resuspended in $50 \mu 150 \mathrm{mM}$ HEPES (pH 7.4), $250 \mathrm{mM} \mathrm{NaCl}, 30 \mathrm{mM} \mathrm{MgCl}, 1$ $\mu \mathrm{M}$ ATP, and $5 \mu \mathrm{Ci}\left[{ }^{32} \mathrm{P}\right] \gamma \mathrm{ATP}$ containing 0.004 units sphingosine kinase. Samples were incubated for $15 \mathrm{~min}$ at $37^{\circ} \mathrm{C}$ with shaking at $300 \mathrm{rpm}$. Controls were incubated with the same buffer without sphingosine kinase or were left untreated. The sphingosine kinase reaction was terminated by centrifugation of the samples at $240 \mathrm{xg}$ for $5 \mathrm{~min}$, removal of the supernatant and addition of $70 \mu_{\mathrm{l} \mathrm{H}} \mathrm{O}$, followed by the addition of $20 \mu \mathrm{l} 1 \mathrm{~N}$ $\mathrm{HCl}, 800 \mu \mathrm{l} \mathrm{CHCl}{ }_{3}: \mathrm{CH}_{3} \mathrm{OH}: 1 \mathrm{~N} \mathrm{HCl}(100: 200: 1, \mathrm{v}: \mathrm{v}: \mathrm{v})$, and $240 \mu \mathrm{l}$ each of $\mathrm{CHCl}_{3}$ and $2 \mathrm{M} \mathrm{KCl}$. The lower phase was collected, dried, dissolved in $20 \mu \mathrm{L} \mathrm{CHCl}_{3}: \mathrm{CH}_{3} \mathrm{OH}(1: 1, \mathrm{v} / \mathrm{v})$, and separated on Silica G60 TLC plates with $\mathrm{CHCl}_{3}: \mathrm{CH}_{3} \mathrm{OH}$ :acetic acid: $\mathrm{H}_{2} \mathrm{O}$ (90:90:15:5, v:v:v:v) as developing solvent. The TLC plates were analyzed with a phosphoimager. Surface sphingosine levels were determined with a standard curve of C18-sphingosine. This assay analyzes sphingosine on the cell surface and, if released, also in large particles that are pelleted by the slow centrifugation, while exosomes or small microparticles are not pelleted and excluded from the analysis. 


\section{Cellular Physiology Cell Physiol Biochem 2017;43:1603-1616 \begin{tabular}{l|l|l} 
DOI: 10.1159/000482024 & $\begin{array}{l}\text { O 2017 The Author(s). Published by S. Karger AG, Basel } \\
\text { www.karger.com/cpb }\end{array}$
\end{tabular}

\section{Ceramide measurements}

Neutrophils were infected with $P$. aeruginosa strain 762 at an MOI of 1 cell per 100 bacteria or left uninfected. The incubations (200 $\mu$ volume) were terminated by extraction in $\mathrm{CHCl}_{3}: \mathrm{CH}_{3} \mathrm{OH}: 1 \mathrm{~N} \mathrm{HCl}$ (100:100:1; v/v/v). The lower phase was collected, dried and resuspended in $20 \mu \mathrm{l}$ of a detergent solution (7.5\% (w/v) n-octylglucopyranoside, $5 \mathrm{mM}$ cardiolipin in $1 \mathrm{mM}$ diethylenetriaminepentaacetic acid), sonicated for $10 \mathrm{~min}$ and $70 \mu \mathrm{l}$ of a reaction mixture containing $10 \mu \mathrm{l}$ diacylglycerol kinase (GE Healthcare Europe, München, Germany), 0.1 M imidazole/HCl (pH 6.6), $0.2 \mathrm{mM}$ diethylenetriaminepentaacetic acid (pH 6.6), $70 \mathrm{mM} \mathrm{NaCl}, 17 \mathrm{mM} \mathrm{MgCl}_{2}$ and $1.4 \mathrm{mM}$ EGTA, $2 \mathrm{mM}$ DTT, $1 \mu \mathrm{M}$ ATP and $10 \mu \mathrm{Ci}\left[{ }^{32} \mathrm{P}\right]$ ATP were added. The kinase reaction was performed for $1 \mathrm{hr}$ at room temperature and terminated by addition of $1 \mathrm{ml} \mathrm{CHCl}{ }_{3}: \mathrm{CH}_{3} \mathrm{OH}: 1 \mathrm{~N} \mathrm{HCl}(100: 100: 1, \mathrm{v} / \mathrm{v} / \mathrm{v}), 170 \mu \mathrm{l}$ buffered saline solution (135 mM NaCl, $1.5 \mathrm{mM}$ $\mathrm{CaCl}_{2}, 0.5 \mathrm{mM} \mathrm{MgCl}_{2}, 5.6 \mathrm{mM}$ glucose, $10 \mathrm{mM}$ HEPES, pH 7.2) and $30 \mu \mathrm{l}$ of a $100 \mathrm{mM}$ EDTA-solution. The lower phase was collected, dried and separated on Silica G60 TLC plates employing chloroform/acetone/ methanol/acetic acid/ $\mathrm{H}_{2} \mathrm{O}$ (50:20:15:10:5, v/v/v/v/v). Ceramide amounts were determined by comparison with a standard curve using $\mathrm{C} 16$ ceramide as substrate. The results are the mean \pm SD from 4 independent experiments. The TLC plates were analyzed with a phosphorimager.

Neutrophil - P. aeruginosa co-incubation experiments

$10^{4}$ neutrophils were resuspended in $20 \mu \mathrm{l} \mathrm{H/S}$ and infected with 5,000 CFU P. aeruginosa strains 762, 1242 or 1245 . The bacteria were added in a volume of $2 \mu \mathrm{l}$. The samples were incubated for $1 \mathrm{hr}$ at $37^{\circ} \mathrm{C}$. Aliquots were then plated on LB plates and colony forming units (CFU) were counted after o/n growth at $37^{\circ} \mathrm{C}$. To restore sphingosine, we incubated $\mathrm{CF}$ and, as controls, also wildtype neutrophils with $10 \mu \mathrm{M}, 25$ $\mu \mathrm{M}$ or $50 \mu \mathrm{M}$ sphingosine or $15 \mu \mathrm{g} / \mathrm{ml}$ acid ceramidase for $45 \mathrm{~min}$ at $37^{\circ} \mathrm{C}$. The cells were washed twice in $\mathrm{H} / \mathrm{S}$ and then infected as above.

\section{Sphingosine- and ROS-mediated killing of P. aeruginosa}

D-erythro-sphingosine (d18:1) was purchased from Avanti Polar Lipids, USA, $\mathrm{H}_{2} \mathrm{O}_{2}$ from Merck, Germany. Sphingosine was dissolved in 10\% octylglucopyranoside (Sigma) at a concentration of $2 \mathrm{mM}$. The stock was sonicated in a bath sonicator for $10 \mathrm{~min}$ immediately prior to addition to the bacteria. Sonication was performed to achieve the formation of micelles. Sphingosine was then immediately added to 1,000 CFU of the P. aeruginosa strains 762, 1242 or 1245 resuspended in ASL-buffer. $\mathrm{H}_{2} \mathrm{O}_{2}$ was diluted in ALS prior to addition to the bacteria. All samples were incubated for $1 \mathrm{hr}$ at $37^{\circ} \mathrm{C}$. An aliquot was then plated on LB plates, cultured $\mathrm{o} / \mathrm{n}$ and the CFUs were counted.

\section{Sphingosine stainings of neutrophils and P. aeruginosa}

Neutrophils were infected for the indicated times as above or left uninfected. Cells were fixed with $1 \%$ PFA in PBS (pH 7.2) for 15 min, washed, permeabilised with $0.1 \%$ Triton in PBS for 15 min, washed, blocked with a buffer containing H/S and $5 \%$ fetal calf serum (FCS) for $15 \mathrm{~min}$ and stained with anti-sphingosine antibodies (clone NHSPH, Alfresa Pharma Corporation, Japan) [19] for $45 \mathrm{~min}$ at room temperature. The antibodies were diluted 1:1000 in H/S containing 5\% FCS. Cells were then washed twice in H/S followed by a 45 min incubation with Cy3-coupled anti-mouse IgM antibodies (1:250 dilution, Jackson ImmunoResearch). The cells were washed again twice in H/S and mounted in Mowiol. The samples were analyzed with a Leica confocal microscope DMIRE2. The magnification was 400 -fold. Shown are representative results of at least 4 independent experiments.

\section{Statistical Methods}

Data are expressed as arithmetic means \pm SD. For the comparison of two independent groups we used Student's t-test. For more than two groups we used ANOVA followed by a post-hoc t-test for all pairwise comparisons applying Bonferroni correction for multiple testing. $P$ values of 0.05 or less (two-tailed) were considered indicative of statistical significance. All values were normally distributed.

\section{Results}

Human CF lungs contain massive amounts of neutrophils (Fig. 1A, B) that are ineffective at eliminating $S$. aureus and $P$. aeruginosa and other typical CF pathogens. Thus, a high number of bacteria are observed in the bronchial debris in CF lungs (Fig. 1A, B). 


\section{Cellular Physiology and Biochemistry}

Fig. 1. Neutrophils and bacteria accumulate in the bronchial lumen of lungs from cystic fibrosis patients. Sections of lung specimen from cystic fibrosis (CF) or donor (healthy) patients were stained with hemalaun and analyzed by light microscopy. A large number of mononuclear cells and rod-like bacteria were detected in the bronchial lumen of CF lungs, while the lumen of the donor lung is free of cells. Panel A shows donor and CF patient lungs at a 400-fold magnification, panel B shows the debris in the airways of CF patients with 1000-fold magnification. The rod-like bacteria are

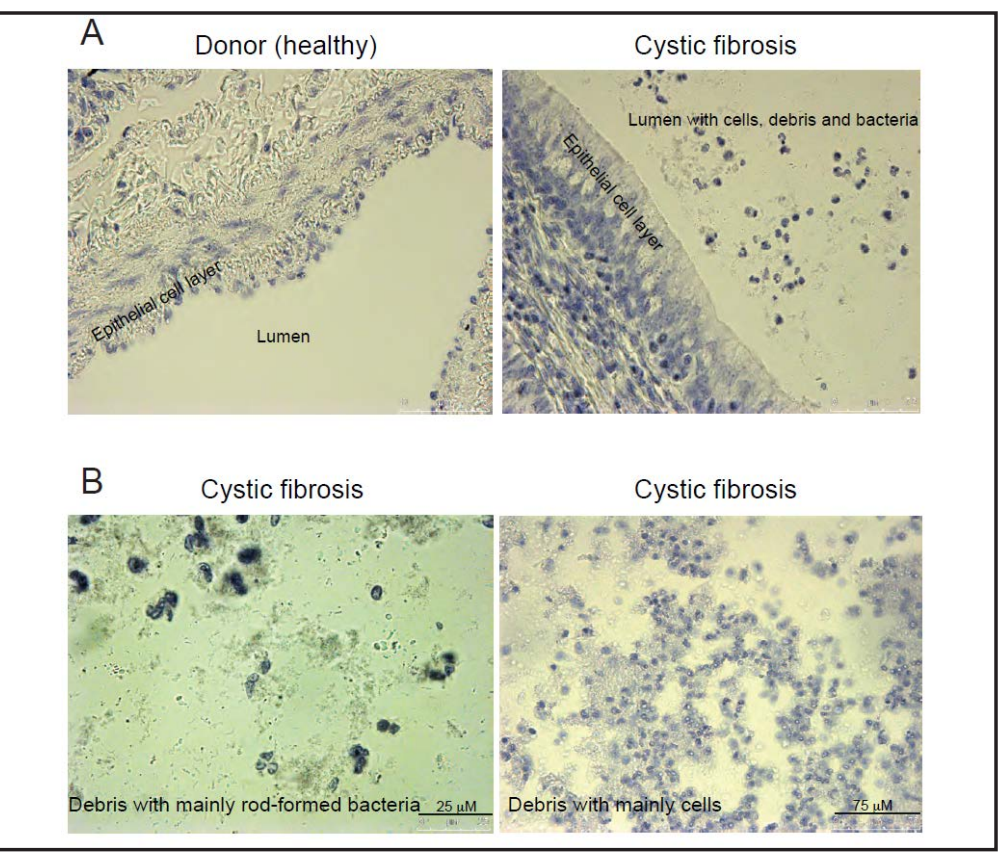
clearly visible in the debris and among the mononuclear cells. Shown is a representative study of 5 samples each.

Fig. 2. Wildtype and cystic fibrosis neutrophils release similar amounts of superoxide, but only wildtype neutrophils kill $P$ aeruginosa. (A) Wildtype and CF neutrophils were infected with 100 bacteria per cell for the indicated times or left uninfected, shock frozen in liquid nitrogen and the release of superoxide was determined by electron spin resonance. The release of superoxide is given in arbitrary units. Shown is the mean \pm SD of 4 independent experiments. ${ }^{*} \mathrm{p}<0.05$ compared to the untreated control of the

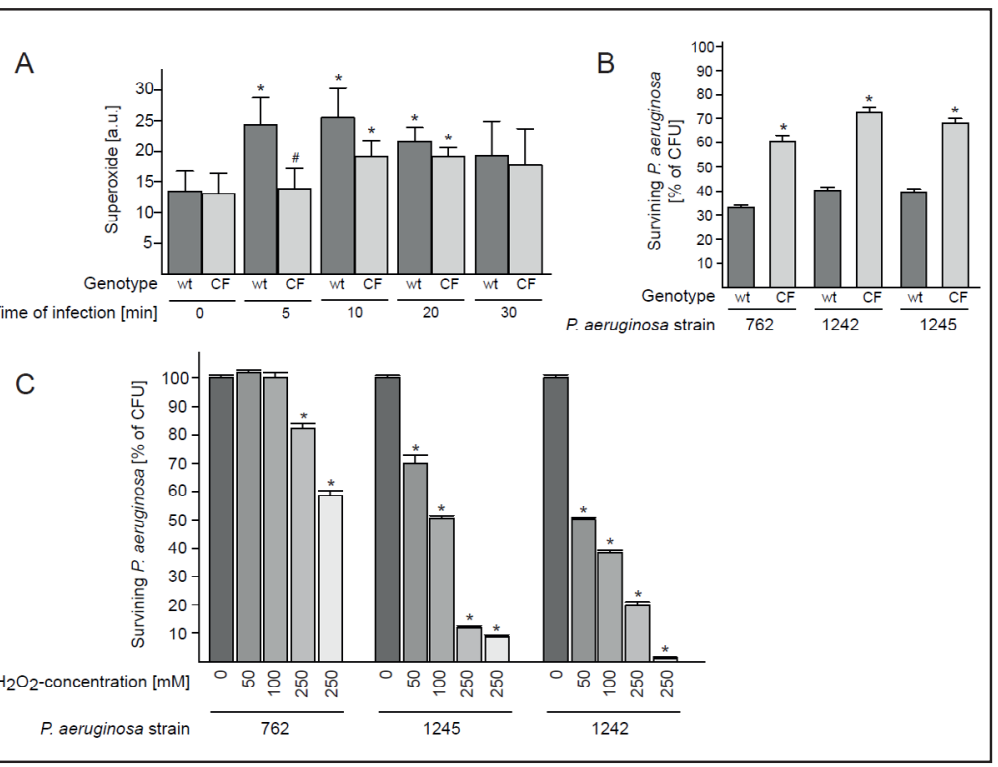
same genotype, " $\mathrm{p}<0.05$ compared to wildtype at the same time, ANOVA and post hoc t-test. (B) Wildtype and CF neutrophils were infected with $P$. aeruginosa at a multiplicity of infection of 1 cell per 0.5 bacteria for $1 \mathrm{hr}$ at $37^{\circ} \mathrm{C}$. The samples were then spotted on agar plates, cultured overnight and the number of the bacteria was determined. Wildtype neutrophils kill the different $P$. aeruginosa strains, while CF neutrophils fail to kill the pathogens. Given is the mean $\pm \mathrm{SD}$ of 4 independent experiments. ${ }^{*} \mathrm{p}<0.05$ compared to wildtype, t-test. (C) Incubation of $P$. aeruginosa strains 762, 1242 or 1245 with increasing concentrations of $\mathrm{H}_{2} \mathrm{O}_{2}$ reveals the high resistance of these strains to reactive oxygen species. Shown is the mean \pm SD of 3 independent experiments. ${ }^{*} \mathrm{p}<0.05$ compared to untreated samples, ANOVA and post hoc t-test.

The release of reactive oxygen species is a prototypical defense mechanism by which neutrophils kill pathogens. We therefore tested whether $C f t$-deficiency impairs this defense 
mechanism. However, our results demonstrated that CF and wildtype neutrophils released comparable amounts of superoxide prior to or after infection with P. aeruginosa (Fig. 2A).

Despite the release of similar amounts of superoxide from CF and wildtype neutrophils, only wildtype neutrophils were able to efficiently kill the clinical non-mucoid and mucoid P. aeruginosa strains 762, 1242 and 1245 (Fig. 2B), indicating that reactive oxygen species alone are insufficient to kill pathogenic $P$. aeruginosa by neutrophils. In addition, all three $P$. aeruginosa strains were rather resistant to reactive oxygen species and only high concentrations $\mathrm{H}_{2} \mathrm{O}_{2}$ at least partly killed the bacteria (Fig. 2C).

We have previously shown that ceramide and sphingosine in epithelial cells of the respiratory tract play an important role in the defense against pathogens [11, 19-21].

Fig. 3. Ceramide is increased and sphingosine decreased in cystic fibrosis neutrophils. (A) Ceramide was measured in wildtype and cystic fibrosis (CF) neutrophils prior and after infection with P. aeruginosa 762 employing a ceramide-kinase assay. Ceramide was extracted and the phosphorylation in the presence of $\left[{ }^{32} \mathrm{P}\right]$ $\gamma$ ATP and a ceramide kinase was measured. Samples were separated by thin layer chromatography and analyzed using a phosphoimager. Ceramide is markedly increased in CF neutrophils compared to wildtype neutrophils. (B) Sphingosine kinase assays of wildtype and CF neutrophils reveal reduced levels of sphingosine in CF compared to wildtype neutrophils. Sphingosine was quantified by phosphorylation in the presence of $\left[{ }^{32} \mathrm{P}\right] \gamma \mathrm{ATP}$ and sphingosine kinase, separation by thin layer chromatography and analysis by a phosphoimager. (C) Wildtype neutrophils release much higher levels of sphingosine into the cell culture supernatant than CF neutrophils. Infection does not change the sphingosine levels in the cell pellet and the supernatants. Sphingosine in the supernatant and post-centrifugation pellets was determined as above. Panels A-C

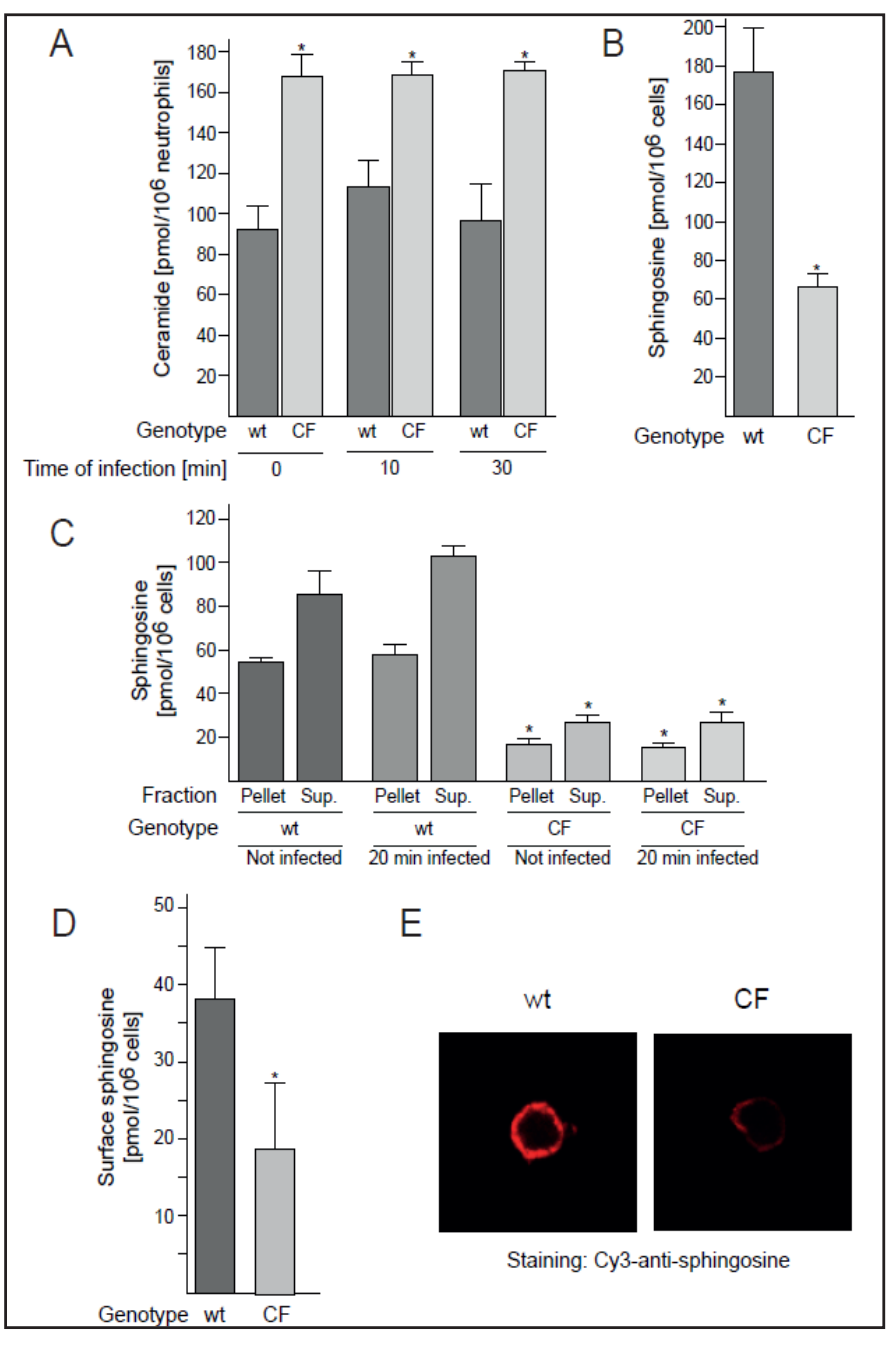
display the mean \pm SD of 4 independent experiments. ${ }^{*} \mathrm{p}<0.05$ compared to wildtype neutrophils with the same treatment, ANOVA and post hoc t-test. (D) Surface sphingosine was quantified by incubation of intact neutrophils freshly isolated from wildtype and CF mice with sphingosine kinase in the presence of $\left[{ }^{32} \mathrm{P} \gamma\right]$ ATP for $15 \mathrm{~min}$ at $37^{\circ} \mathrm{C}$. Cells were then extracted, lipids were separated by thin layer chromatography and radioactive sphingosine 1-phosphate was quantified. The ratio between radioactive and non-radioactive ATP present in the kinase buffer was taken into account to calculate the total amount of surface sphingosine. Shown is the mean \pm SD from 3 independent samples. ${ }^{*} \mathrm{p}<0.05$ compared to wildtype, $t$-test. (E) Intact, nonpermeabilized wildtype or cystic fibrosis (CF) neutrophils were stained with Cy3-coupled anti-sphingosine antibodies. Confocal microscopy studies revealed a higher sphingosine expression in the outer leaflet of the plasma membrane of wildtype neutrophils than in CF neutrophils. Shown are representative studies from 4 independent experiments. 
Sphingosine very rapidly and efficiently kills $P$. aeruginosa and $S$. aureus in vitro and in vivo in the lung [19-21, 30]. We have also shown that sphingosine levels are greatly reduced in the epithelial cells of the upper airways in CF, and that this lack of sphingosine results in the failure of upper airway epithelial cells in CF to kill invading pathogens before they reach the lung [21]. However, a potential role of ceramide or sphingosine in neutrophils and their response to $P$. aeruginosa is presently unknown. We therefore investigated the expression pattern of ceramide and sphingosine in wildtype and CF neutrophils. Here, we demonstrate a marked increase of ceramide in CF neutrophils compared to wildtype neutrophils (Fig. 3A). Infection with $P$. aeruginosa strain 762 did not further increase ceramide levels.

Total cellular sphingosine was markedly reduced in CF compared to wildtype neutrophils (Fig. 3B). Moreover, wildtype neutrophils released a high amount of sphingosine in the culture supernatant (Fig. 3C). The constitutive release of sphingosine into the culture supernatant was much lower in cultures from CF neutrophils (Fig. 3C). Infection did not significantly

Fig. 4. Sphingosine accumulates in $P$. aeruginosa after infection of wildtype neutrophils. Confocal microscopy studies demonstrate the presence of sphingosine in P. aeruginosa strain 762 20 min after infection of wildtype neutrophils, while incubation of the bacteria with cystic fibrosis (CF) neutrophils results in much lower sphingosine incorporation in P. aeruginosa. Shown are representative Figures from 4 independent experiments.

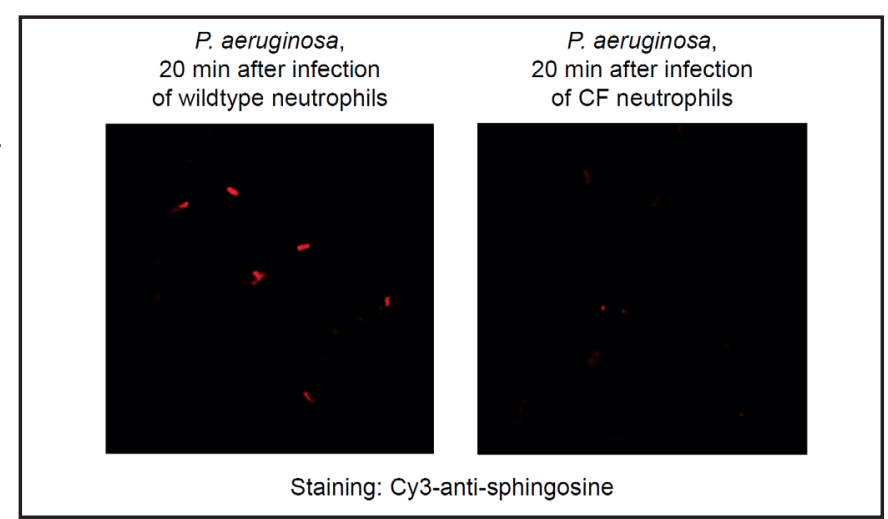

Fig. 5. Killing of P. aeruginosa by sphingosine and $\mathrm{H}_{2} \mathrm{O}_{2}$ in vitro. Low micromolar concentrations of sphingosine kill $P$. aeruginosa strains 762 (A), 1242 (B) and 1245 (C). These strains are rather resistant to reactive oxygen species (A-C). Reactive oxygen species and sphingosine did not synergize in killing $P$. aeruginosa. 1000 CFU of the $P$. aeruginosa strains were incubated for $60 \mathrm{~min}$ at $37^{\circ} \mathrm{C}$ with the indicated concentration of sphingosine or $\mathrm{H}_{2} \mathrm{O}_{2}$ or both, the samples were plated on agar, grown overnight and the CFU were counted. Shown is the mean \pm SD of 4 independent experiments. ${ }^{* *} \mathrm{p}<0.01,{ }^{* * *} \mathrm{p}<0,001$ compared to untreated controls, ANOVA and post hoc t-test.

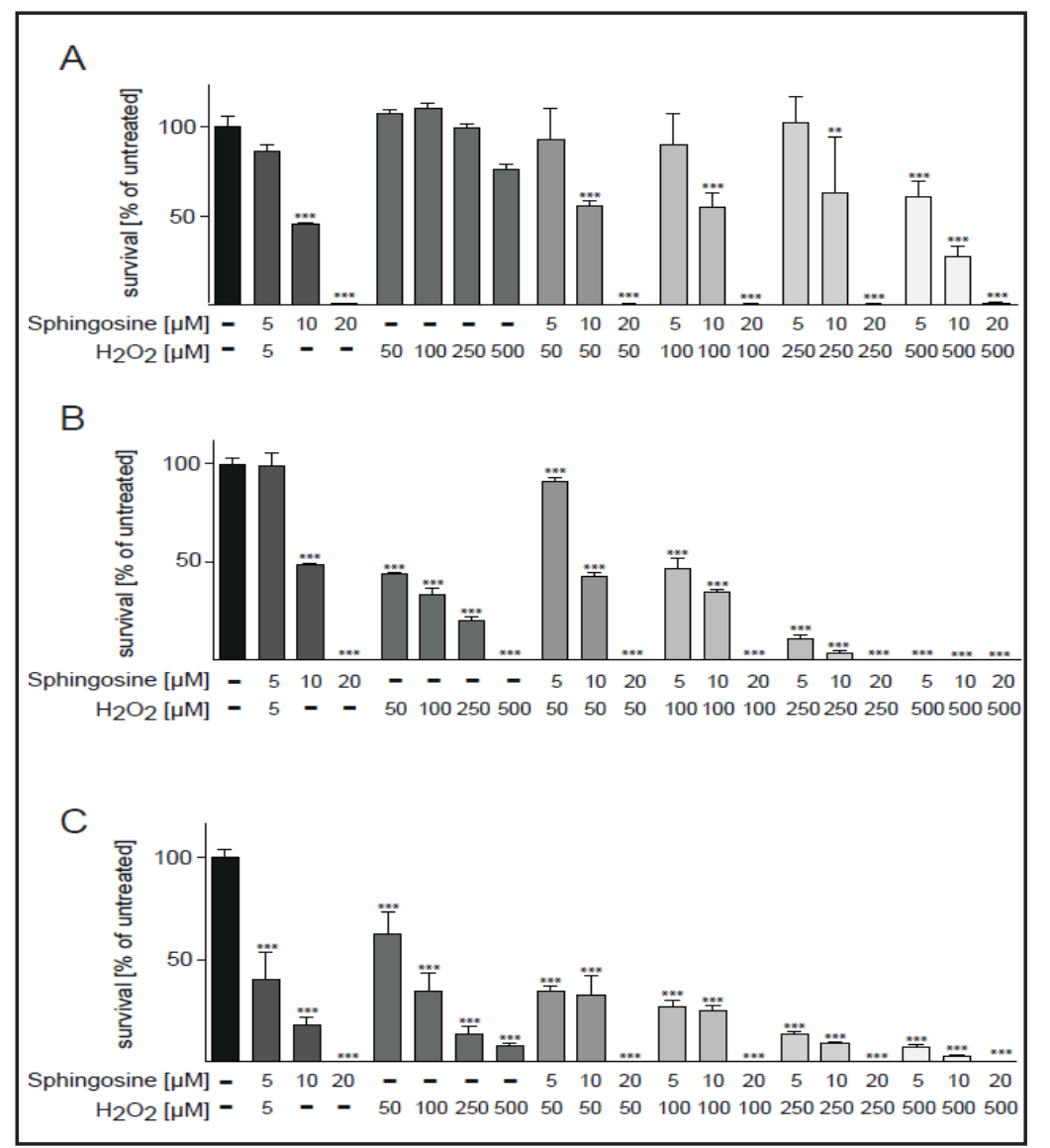

\section{KARGER}


change the cellular concentration or the release of sphingosine into the culture supernatant (Fig. 3C).

Since the concentration of sphingosine on the cell surface determines the effect of cellular sphingosine on pathogens, we determined the surface concentration of sphingosine by a kinase assay and by immunofluorescence studies. In the surface kinase assays intact neutrophils are incubated with sphingosine kinase in the presence of $\left[{ }^{32} \mathrm{P}\right] \gamma \mathrm{ATP}$. The kinase reaction results in the conversion of surface sphingosine to radioactive sphingosine 1-phosphate. Extraction of lipids then allows quantification of surface sphingosine. In the immunofluorescence studies, intact neutrophils were stained with Cy3labelled anti-sphingosine antibodies and analyzed by confocal microscopy. Both methods demonstrated a marked down-regulation of surface sphingosine in CF neutrophils compared to wildtype neutrophils (Fig. 3D and E).

The confocal microscopy studies also revealed the presence of sphingosine in $P$. aeruginosa 20 min after infection of wildtype neutrophils, indicating a direct interaction of sphingosine with $P$. aeruginosa upon the release from neutrophils (Fig. 4). The incorporation of sphingosine by $P$. aeruginosa was much lower after infection of CF neutrophils (Fig. 4).

To gain insight into whether sphingosine in neutrophils contributes to killing of bacteria by these cells, we tested whether exogenously added sphingosine kills $P$. aeruginosa. These studies revealed killing of the $P$. aeruginosa strains 762,1242 and 1245 by sphingosine

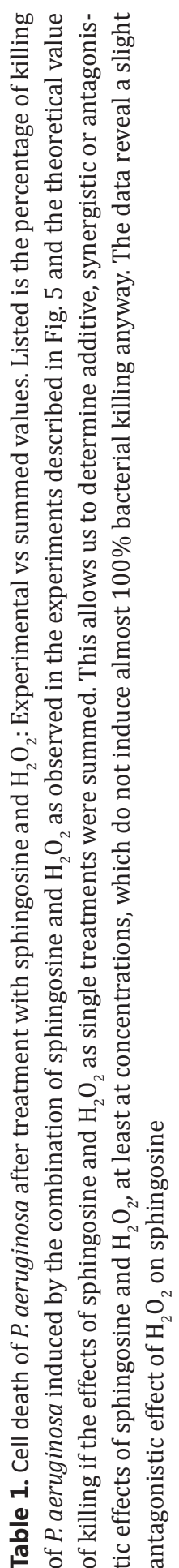

at low micromolar concentrations (Fig. 5A-C). Finally, we investigated whether reactive oxygen species and sphingosine synergize. However, the results revealed that reactive oxygen species and sphingosine did not synergize to kill $P$. aeruginosa (Fig. 5A-C). Table 1 shows comparison between hypothetical and actual additive effects of sphingosine and $\mathrm{H}_{2} \mathrm{O}_{2}$. The data reveal that sphingosine and $\mathrm{H}_{2} \mathrm{O}_{2}$ are not synergistic and even slightly antagonistic, at least for intermediate $\mathrm{H}_{2} \mathrm{O}_{2}$ concentrations. 
Fig. 6. Reconstitution of sphingosine in cystic fibrosis neutrophils restores killing of P. aeruginosa. Addition of sphingosine to cystic fibrosis (CF) neutrophils or generation of endogenous sphingosine restores the bactericidal capacity of CF neutrophils and killing of the clinical $P$. aeruginosa strains 762 (A), 1245 (B) and 1242 (C). CF or wildtype neutrophils were treated with $10 \mu \mathrm{M}$, $25 \mu \mathrm{M}$ or $50 \mu \mathrm{M}$ sphingosine (SPH) or $250 \mu \mathrm{g} / \mathrm{ml}$ acid ceramidase (AC) for $45 \mathrm{~min}$ at $37^{\circ} \mathrm{C}$, extensively washed, infected and the number of bacteria was determined after overnight growth on agar plates. Shown is the mean \pm SD of each 4 independent experiments. ${ }^{*} \mathrm{p}<0.05$ compared to untreated of the same genotyope, $\# \mathrm{p}<0.05$ compared between wildtype and CF neutrophils with the same treatment, ANOVA and post hoc t-test.

To prove a role of sphingosine in neutrophils for killing of P. aeruginosa, we reconstituted sphingosine in CF neutrophils by treatment with sphingosine or acid ceramidase, which generates sphingosine from ceramide [35]. These treatments completely restored the bactericidal capacity of CF neutrophils, which were now able to kill the clinical P. aeruginosa strains 762,1242 and 1245 as efficient as wildtype neutrophils (Fig. 6A-C).

\section{Discussion}

In the present study we provide evidence for a novel mechanism of how neutrophils kill at least some clinical strains of $P$. aeruginosa. Although $\mathrm{CF}$ and wildtype neutrophils release similar amounts of superoxide, CF neutrophils have a reduced capacity to kill $P$. aeruginosa indicating that this mechanism alone is insufficient to kill these bacteria. We also demonstrate that these clinical isolates of $P$. aeruginosa are relatively resistant to reactive oxygen species. Wildtype neutrophils overcome this resistance by sphingosine-mediated killing of $P$. aeruginosa. In contrast, sphingosine is markedly reduced in CF neutrophils, resulting in a failure of these cells to kill $P$. aeruginosa. Reconstitution of sphingosine in $\mathrm{CF}$ neutrophils is sufficient to restore the ability of CF neutrophils to kill $P$. aeruginosa. In fact, addition of acid ceramidase to CF neutrophils restored killing of $P$. aeruginosa by these cells even over the level of wildtype neutrophils. We assume that this is caused by a high formation of sphingosine from ceramide, which is accumulated in CF neutrophils.

It is important to note that we investigated the role of sphingosine in neutrophils on killing of planktonic and mucoid $P$. aeruginosa, representing the clinically most relevant forms of this pathogen inducing acute and chronic pneumonia. 


\section{Cellular Physiology Cell Physiol Biochem 2017;43:1603-1616

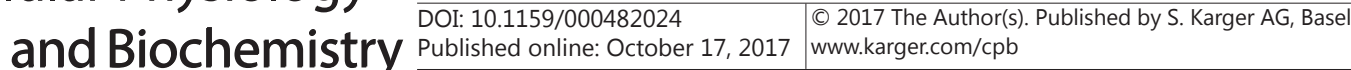 \\ Becker et al.: Regulation of Neutrophil Function in Cystic Fibrosis}

It is surprising that all three tested $P$. aeruginosa strains are resistant to rather high concentrations of reactive oxygen species. However, $P$. aeruginosa is a very versatile pathogen and has developed multiple pathways to deal with potentially toxic exogenous compounds. For instance, it has been shown that $P$. aeruginosa neutralizes reactive oxygen species by tryptophan metabolites [36], expression of catalases [37], superoxide dismutase [38], etc. In this context, it is interesting to note that all three $P$. aeruginosa strains are sensitive to sphingosine.

At present, the mechanism(s) underlying killing of $P$. aeruginosa by sphingosine are unknown. At least $P$. aeruginosa PA0-1 expresses sphingosine response elements, i.e. sphA, which are specifically induced by sphingosine via a sphingosine-specific transcription factor (PA5324), a member of the AraC-family transcription factor, named SphR [39]. Deletion of the SphR transcription factor resulted in reduced bacterial survival during mouse lung infection and increased sensitivity of the pathogen to the antimicrobial effects of sphingosine. Thus, $P$. aeruginosa seems to be able to express sphingosine-binding molecules and factors that protect the pathogen from sphingosine effects, at least partially.

Lower concentrations of free sphingosine (in the nanomolar range) activate the transcriptional regulator SphR in P. aeruginosa, which results in secretion of a bacterial ceramidase [40]. If the cells release only small amounts of sphingosine or if the released sphingosine binds to proteins that reduce the free concentration of sphingosine, the concentration of free sphingosine would be too low to kill the bacteria immediately and instead would activate SphR. Bacterial ceramidase may induce sphingosine on the surface of mammalian cells. However, our data argue against such a scenario, since the concentration of ceramide on the cell surface of wildtype cells was low.

Thus, from the point of view of neutrophils it is important to kill P. aeruginosa very rapidly with a high concentration of sphingosine delivered to the bacteria without neutralization by proteins and prior to the release of ceramidase and damage to the host cells.

Our studies demonstrate that a small increase of sphingosine concentration from $5 \mu \mathrm{M}$ to $20 \mu \mathrm{M}$ is already sufficient to kill $100 \%$ of the bacteria. It seems unlikely that classical biochemical pathways mediate the sharp increase of the effects of sphingosine, and we assume that the bacterio-toxic effects of sphingosine are mainly mediated by biophysical mechanisms, such as integration into bacterial membranes and disruption of their function. However, at present it is unknown how sphingosine kills pathogens.

We also investigated whether reactive oxygen species and sphingosine may act synergistically. The data do not provide any synergistic effect of the two mediators on bacterial growth. In fact, higher concentrations of $\mathrm{H}_{2} \mathrm{O}_{2}$ seem to reduce the effects of sphingosine on bacterial killing. It is possible that oxidation of the double bond in sphingosine might at least partly inactivate the molecule. This assumption is consistent with the previous observation that sphinganine, lacking a double bond compared to sphingosine, is much less bactericidal than sphingosine [19], although sphinganine is not an oxidation product of sphingosine.

Thus, it is tempting to speculate that the high number of neutrophils continuously present in the lungs of CF patients produce high concentrations of reactive oxygen species that oxidize sphingosine, which is already reduced in these cells, and thereby further reducing the bactericidal effects of neutrophils and also the effects of epithelial cell-derived sphingosine on invading pathogens. This would result in a vicious cycle in the lungs of CF patients with more neutrophils, a lack of sphingosine in these cells, and further inactivation of the remaining sphingosine by reaction with reactive oxygen species finally resulting in the lack of killing of $P$. aeruginosa. This vicious cycle could be interrupted by inhalation of CF patients with acid ceramidase and/or direct application of sphingosine into the lung. In addition, the continuous release of reactive oxygen species from CF neutrophils in the lung may also damage the lung tissue and contribute to the typical development of CF.

Our studies demonstrate that sphingosine is present in cell culture supernatants and also indicate that sphingosine is incorporated into the bacteria and can be visualized by staining with a sphingosine-specific antibody [19]. Since sphingosine is insoluble in water, it might be present in microvesicles or exosomes [41-43]. These microparticles might be 


\section{Cellular Physiology Cell Physiol Biochem 2017;43:1603-1616 \\ and Biochemistry DOI: 10.1159/000482024 \begin{tabular}{l|l} 
O 2017 The Author(s). Published by S. Karger AG, Basel \\
wwww.karger.com/cpb
\end{tabular} \\ Becker et al.: Regulation of Neutrophil Function in Cystic Fibrosis}

shed from the surface of neutrophils [44] and/or released from multivesicular bodies [45], and fuse with bacterial membranes resulting in incorporation of sphingosine in the bacterial membrane and killing of the pathogen. However, it might be also possible that sphingosine is transferred from the neutrophil membrane after contact with bacterial membranes, although this would require a higher affinity of the bacterial membrane for sphingosine than the mammalian counterpart.

We have previously shown that sphingosine expressed in airway epithelial cells plays an important role in the prevention and defense of P. aeruginosa infections in CF mice and after burn-injury [19-21, 42]. These studies revealed that sphingosine is expressed predominantly in upper airway epithelial cells and reduced in CF mice or in wildtype mice subjected to burn-injury. Reconstitution of sphingosine in epithelial cells prevented acute pulmonary infections with $P$. aeruginosa. In vitro studies demonstrated that sphingosine kills many bacterial species, for instance P. aeruginosa, Staphylococcus aureus, Moraxella catarrhalis, Haemophilus influenzae, Burkholderia species and Escherichia coli $[19,46,47]$. While these studies investigated the effect of sphingosine in airway epithelial cells on infections, they did not study the expression and role in neutrophils or other classical cells of the innate immune system for their response to pathogens.

Our studies demonstrate that sphingosine plays an important anti-bacterial role in neutrophils. However, they certainly do not exclude that other mechanisms such as the release of proteases [43] or NO-radicals [48] are also involved in killing of pathogens. Further, although clinically-relevant $P$. aeruginosa strains are resistant to reactive oxygen species, these radicals might be the predominant mechanisms in killing of other bacterial species.

\section{Conclusion}

We demonstrate that several clinical $P$. aeruginosa strains are resistant to reactive oxygen species. Although neutrophils from wildtype or CF mice produce similar amounts of superoxide, only wildtype neutrophils are able to kill these $P$. aeruginosa strains, while CF neutrophils fail to do so. Wildtype neutrophils kill $P$. aeruginosa at least in part by expression and release of sphingosine, and reconstitution of sphingosine in CF neutrophils restores their capability to kill P. aeruginosa strains. These data establish a novel paradigm for killing of $P$. aeruginosa by neutrophils, but also provide novel options for the reconstitution of antibacterial functions of CF neutrophils, for instance by application of acid ceramidase, which consumes increased ceramide in these neutrophils to sphingosine.

\section{Acknowledgements}

The study was supported by DFG-grant Gu 335/35-1 to EG and GRK 2098 to KAB and EG.

\section{Disclosure Statement}

The authors have no conflicts of interest to disclose.

\section{References}

1 Rommens JM, Iannuzzi MC, Kerem B, Drumm ML, Melmer G, Dean M, Rozmahel R, Cole JL, Kennedy D, Hidaka N, Zsiga M, Buchwald M, Riordan JR, Tsui LC, Collins FS: Identification of the cystic fibrosis gene: Chromosome walking and jumping. Science 1989;245:1059-1065.

2 Cystic fibrosis registry of the USA, www.cff.org

3 Döring G, Gulbins E: Cystic fibrosis and innate immunity: how chloride channel mutations provoke lung disease. Cell Microbiol 2009;11:208-216.

4 Matsui H, Grubb BR, Tarran R, Randell SH, Gatzy JT, Davis CW, Boucher RC: Evidence for periciliary liquid layer depletion, not abnormal ion composition, in the pathogenesis of cystic fibrosis airways disease. Cell 1998;95:1005-1015. 


\section{Cellular Physiology Cell Physiol Biochem 2017;43:1603-1616 \begin{tabular}{l|l|l} 
and BOI: 10.1159/000482024 & $\begin{array}{l}\text { C } 2017 \text { The Author(s). Published by S. Karger AG, Basel } \\
\text { www.karger.com/cpb }\end{array}$
\end{tabular} \\ Becker et al.: Regulation of Neutrophil Function in Cystic Fibrosis}

5 Matsui H, Verghese MW, Kesimer M, Schwab UE, Randell SH, Sheehan JK, Grubb BR, Boucher RC: Reduced three-dimensional motility in dehydrated airway mucus prevents neutrophil capture and killing bacteria on airway epithelial surfaces. J Immunol 2005;175:1090-1099.

6 Locke LW, Myerburg MM, Weiner DJ, Markovetz MR, Parker RS, Muthukrishnan A, Weber L, Czachowski MR, Lacy RT, Pilewski JM, Corcoran TE: Pseudomonas infection and mucociliary and absorptive clearance in the cystic fibrosis lung. Eur Respir J 2016;47:1392-1401.

7 Cohen TS, Prince A: Cystic fibrosis: a mucosal immunodeficiency syndrome. Nat Med 2012;18:509-519.

-8 Pohl K, Hayes E, Keenan J, Henry M, Meleady P, Molloy K, Jundi B, Bergin DA, McCarthy C, McElvaney OJ, White MM, Clynes M, Reeves EP, McElvaney NG: A neutrophil intrinsic impairment affecting Rab27a and degranulation in cystic fibrosis is corrected by CFTR potentiator therapy. Blood 2014;124:999-1009.

-9 Shah VS, Meyerholz DK, Tang XX, Reznikov L, Abou Alaiwa M, Ernst SE, Karp PH, Wohlford-Lenane CL, Heilmann KP, Leidinger MR, Allen PD, Zabner J, McCray PB Jr, Ostedgaard LS, Stoltz DA, Randak CO, Welsh MJ: Airway acidification initiates host defense abnormalities in cystic fibrosis mice. Science 2016;351:503507.

10 Sverdlov VE, Kostina MB, Modyanov NN: Genomic organization of the human ATP1AL1 gene encoding a ouabain-sensitive H,K-ATPase. Genomics 1996;32:317-327.

11 Teichgräber V, Ulrich M, Endlich N, Riethmüller J, Wilker B, De Oliveira-Munding CC, van Heeckeren AM, Barr ML, von Kürthy G, Schmid KW, Weller M, Tümmler B, Lang F, Grassme H, Döring G, Gulbins E: Ceramide accumulation mediates inflammation, cell death and infection susceptibility in cystic fibrosis. Nat Med 2008;14:382-391.

12 Becker KA, Riethmüller J, Lüth A, Döring G, Kleuser B, Gulbins E: Acid sphingomyelinase inhibitors normalize pulmonary ceramide and inflammation in cystic fibrosis. AJRCMB 2010;42:716-724.

13 Becker KA, Tümmler B, Gulbins E, Grassmé H: Accumulation of ceramide in the trachea and intestine of cystic fibrosis mice causes inflammation and cell death. Biophys Biochem Res Comm 2010;403:368-374.

$\checkmark 14$ Bodas M, Min T, Mazur S, Vij N: Critical modifier role of membrane-cystic fibrosis transmembrane conductance regulator-dependent ceramide signaling in lung injury and emphysema. J Immunol 2011;186:602-613.

15 Bodas M, Min T, Vij N: Critical role of CFTR-dependent lipid rafts in cigarette smoke-induced lung epithelial injury. Am J Physiol Lung Cell Mol Physiol 2011;300:L811-820.

-16 Brodlie M, McKean MC, Johnson GE, Gray J, Fisher AJ, Corris PA, Lordan JL, Ward C: Ceramide is increased in the lower airway epithelium of people with advanced cystic fibrosis lung disease. Am J Respir Crit Care Med 2010;182:369-375.

-17 Ulrich M, Worlitzsch D, Viglio S, Siegmann N, Iadarola P, Shute JK, Geiser M, Pier GB, Friedel G, Barr ML, Schuster A, Meyer KC, Ratjen F, Bjarnsholt T, Gulbins E, Döring G: Alveolar inflammation in cystic fibrosis. J Cyst Fibros 2010;9:217-227.

18 Zhang Y, Li X, Grassmé H, Döring G, Gulbins E: Alterations in ceramide concentration and pH determine the release of reactive oxygen species by Cftr-deficient macrophages on infection. J Immunol 2009;184: 5104-5111.

19 Pewzner-Jung Y, Tavakoli Tabazavareh S, Grassmé H, Becker KA, Japtok L, Steinmann J, Joseph T, Lang S, Tuemmler B, Schuchman EH, Lentsch AB, Kleuser B, Edwards MJ, Futerman AH, Gulbins E: Sphingoid long chain bases prevent lung infection by Pseudomonas aeruginosa. EMBO Mol Med 2014;6:1205-1214.

-20 Tavakoli Tabazavareh S, Seitz A, Jernigan P, Sehl C, Keitsch S, Lang S, Kahl BC, Edwards M, Grassmé H, Gulbins E, Becker KA: Lack of sphingosine causes susceptibility to pulmonary Staphylococcus aureus infections in cystic fibrosis. Cell Physiol Biochem 2016;38:2094-2102.

21 Grassmé H, Henry B, Ziobro R, Becker KA, Riethmüller J, Gardner A, Seitz AP, Steinmann J, Lang S, Ward C, Schuchman EH, Caldwell CC, Kamler M, Edwards MJ, Brodlie M, Gulbins E: $\beta 1$-Integrin accumulates in cystic fibrosis luminal airway epithelial membranes and decreases sphingosine, promoting bacterial infections. Cell Host Microbe 2017;21:707-718.

-22 Garić D, De Sanctis JB, Wojewodka G, Houle D, Cupri S, Abu-Arish A, Hanrahan JW, Hajduch M, Matouk E, Radzioch D: Fenretinide differentially modulates the levels of long- and very long-chain ceramides by downregulating Cers5 enzyme: evidence from bench to bedside. J Mol Med (Berl). 2017,doi: 10.1007/ s00109-017-1564-y

23 Gulbins E, Palmada M, Reichel M, Lüth A, Böhmer C, Amato D, Müller CP, Tischbirek CH, Groemer TW, Tabatabai G, Becker KA, Tripal P, Staedtler S, Ackermann TF, v. Brederode J, Alzheimer C, Weller M, Lang UE, Kleuser B, Grassmé H, Kornhuber J: Acid sphingomyelinase/ceramide system mediates effects of antidepressant drugs. Nat Med 2013;19:934-938.

24 Kornhuber J, Medlin A, Bleich S, Jendrossek V, Henkel AW, Wiltfang J, Gulbins E: High activity of acid sphingomyelinase in major depression. J Neural Transm 2005;112:1583-1590. 


\section{Cellular Physiology Cell Physiol Biochem 2017;43:1603-1616

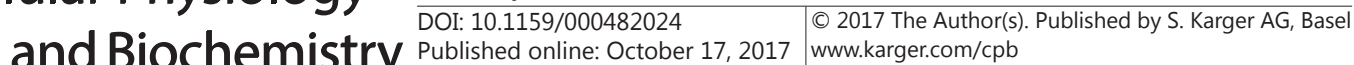

25 Grassmé H, Jendrossek V, Riehle A, von Kurthy G, Berger J, Schwarz H, Weller M, Kolesnick R, Gulbins E: Host defense against Pseudomonas aeruginosa requires ceramide-rich membrane rafts. Nat Med 2003;9:322-330.

26 Grassmé H, Jekle A, Riehle A, Schwarz H, Berger J, Sandhoff K, Kolesnick R, Gulbins E: CD95 signaling via ceramide-rich membrane rafts. J Biol Chem 2001;276:20589-20596.

-27 Zhang AY, Yi F, Jin S, Xia M, Chen QZ, Gulbins E, Li PL: Acid sphingomyelinase and its redox amplification in formation of lipid raft redox signaling platforms in endothelial cells. Antioxid Redox Signal 2007;9:817-828.

-28 Nicolay JP, Gatz S, Liebig G, Gulbins E, Lang F: Amyloid induced suicidal erythrocyte death. Cell Physiol Biochem 2007;19:175-184.

29 Lang E, Gatidis S, Freise NF, Bock H, Kubitz R, Lauermann C, Orth HM, Klindt C, Schuier M, Keitel V, Reich M, Liu G, Schmidt S, Xu HC, Qadri SM, Herebian D, Pandyra AA, Mayatepek E, Gulbins E, Lang F, Häussinger D, Lang KS, Föller M, Lang PA: Conjugated bilirubin triggers anemia by inducing erythrocyte death. Hepatology 2015;61:275-284.

30 Martin GE, Boudreau RM, Couch C, Becker KA, Edwards MJ, Caldwell CC, Gulbins E, Seitz A: Sphingosine's role in epithelial host defense: A natural antimicrobial and novel therapeutic. Biochimie 2017;S03009084(17)30065-2 doi: 10.1016/j.biochi.2017.03.014.

-31 Becker KA, Henry B, Ziobro R, Riethmüller J, Gulbins E: Lipids in cystic fibrosis. Expert Rev Respir Med 2011;5:527-535.

32 Grassmé H, Kirschnek S, Riethmueller J, Riehle A, von Kürthy G, Lang F, Weller M, Gulbins E: CD95/CD95 ligand interactions on epithelial cells in host defense to Pseudomonas aeruginosa. Science 2000;290:527530.

-33 Baconnais S, Tirouvanziam R, Zahm JM, de Bentzmann S, Peault B, Balossier G, Puchelle E: Ion composition and rheology of airway liquid from cystic fibrosis fetal tracheal xenografts. Am J Respir Cell Mol Biol 1999;20:605-611.

-34 Chen Y, Wang L, Pitzer AL, Li X, Li P-L, Zhang Y: Contribution of redox-dependent activation of endothelial Nlrp3 inflammasomes to hyperglycemia-induced endothelial dysfunction. J Mol Med 2016;94:1335-1347.

-35 Park JH, Schuchman EH: Acid ceramidase and human disease. Biochim Biophys Acta 2006;1758:21332138.

-36 Genestet C, Le Gouellec A, Chaker H, Polack B, Guery B, Toussaint B, Stasia MJ: Scavenging of reactive oxygen species by tryptophan metabolites helps Pseudomonas aeruginosa escape neutrophil killing. Free Radic Biol Med 2014;73:400-410.

-37 Campbell JJ, Hoggla, Strasdine GA: Enzyme distribution in Pseudomonas aeruginosa. J Bacteriol 1962;83:1155-1160.

-38 Sethupathy S, Prasath KG, Ananthi S, Mahalingam S, Balan SY, Pandian SK: Proteomic analysis reveals modulation of iron homeostasis and oxidative stress response in Pseudomonas aeruginosa PA01 by curcumin inhibiting quorum sensing regulated virulence factors and biofilm production. J Proteomics 2016;145:112-126.

39 LaBauve AE, Wargo MJ: Detection of host-derived sphingosine by P. aeruginosa is important for survival of the pathogen in the murine lung. PLos Pathog 2014;10:e1003889.

40 Okino N, Ito M: Molecular mechanism for sphingosine-induced Pseudomonas ceramidase expression through the transcriptional regulator SphR. Sci Rep 2016;6:38797.

-41 Greening DW, Xu R, Gopal SK, Rai A, Simpson RJ: Proteomic insights into extracellular vesicle biology defining exosomes and shed microvesicles. Expert Rev Proteomics 2017;14:69-95.

-42 Rice TC, Seitz AP, Edwards MJ, Gulbins E, Caldwell CC: Frontline Science: Sphingosine rescues burn-injured mice from pulmonary Pseudomonas aeruginosa infection. J Leukoc Biol 2016, 100:1233-1237.

43 Wright DG, Malawista SE: The mobilization and extracellular release of granular enzymes from human leukocytes during phagocytosis. J Cell Biol 1972;53:788-797.

-44 Bianco F, Perrotta C, Novellino L, Francolini M, Riganti L, Menna E, Saglietti L, Schuchman EH, Furlan R, Clementi E, Matteoli M, Verderio C: Acid sphingomyelinase activity triggers microparticle release from glial cells. EMBO J 2009;28:1043-1054.

45 Nojima H, Freeman CM, Schuster RM, Japtok L, Kleuser B, Edwards MJ, Gulbins E, Lentsch AB: Hepatocyte exosomes mediate liver repair and regeneration via sphingosine-1-phosphate. J Hepatol 2016;64:60-68.

46 Bibel DJ, Aly R, Shinefield HR: Antimicrobial activity of sphingosines. J Invest Dermatol 1992;98:269-273.

-47 Fischer CL, Drake DR, Dawson DV, Blanchette DR, Brogden KA, Wertz PW: Antibacterial activity of sphingoid bases and fatty acids against Gram-positive and Gram-negative bacteria. Antimicrob Agents Chemother 2012;56:1157-1161.

48 Zhang Y, Li X, Carpinteiro A, Goettel JA, Soddemann M, Gulbins E: Kinase suppressor of Ras-1 protects against pulmonary Pseudomonas aeruginosa infections. Nat Med 2011;17:341-346. 